\title{
Adult Gaucher disease in association with acute leukaemia
}

\author{
G.M. Corbett, P.J. Darbyshire, G.T.N. Besley' ${ }^{1}$ and A.C. Parker \\ Department of Haematology, Royal Infirmary of Edinburgh, Lauriston Place, Edinburgh and 'Royal Hospital for \\ Sick Children, Edinburgh, UK.
}

\begin{abstract}
Summary: A non-Jewish patient diagnosed as having Gaucher disease at the age of 67 is described. Fourteen months after presentation he was diagnosed as having acute myeloid leukaemia. A possible association between Gaucher disease and acute myeloid leukaemia is suggested.
\end{abstract}

\section{Introduction}

The adult (Type 1) form of Gaucher disease is probably the most prevalent glycolipid storage disease, usually occurring in Jewish patients and often presenting in the second or third decade of life. ${ }^{1}$ The disease results from a deficiency of $\beta$ glucocerebrosidase ( $\beta$-glucosidase) activity and is characterized by the presence of large and characteristic lipid-laden macrophages or Gaucher cells, particularly in the spleen but also in bone marrow, liver and lymph nodes. A few cases of proven Gaucher disease associated with leukaemia have been reported. ${ }^{2-4}$ We describe a patient with adult Gaucher disease who progressed to develop acute non-lymphoid leukaemia.

\section{Case report}

A 67 year old man of Scottish birth and ancestry presented in September 1982 with a history of increasing fatigue over a 12 month period. He also complained of central chest pain on exertion for which his general practitioner had been prescribing nifedipine. There was a past history of heavy alcohol intake, but this had moderated in recent years. He had two brothers and two children, all of whom were alive and well.

Examination showed a man with sallow and waxy skin who did not appear ill. The only positive finding was a $4 \mathrm{~cm}$ enlarged spleen. Investigation showed a haemoglobin concentration of $9.2 \mathrm{~g} / \mathrm{dl}$, total white cell count of $3.3 \times 10^{9} / 1$ and platelet count of $18 \times 10^{9} / 1$. Routine biochemistry, including liver function tests and acid phosphatase, was normal. Chest and bone

Correspondence: G.M. Corbett, M.B., Ch.B. M.R.C.P. (UK), M.R.C. Path., Department of Haematology, Western General Hospital, Crewe Road, Edinburgh EH4 2KU, UK. Accepted: 26 March 1987 radiographs were unremarkable and abdominal computed tomographic (CT) scan confirmed his splenomegaly but revealed no other pathology. Both red cell and indium labelled platelet survival were shortened with an increase in splenic uptake. These initial investigations were consistent with moderate hypersplenism. Further investigation revealed the bone marrow aspirate to be heavily infiltrated with mature histiocytes (periodic acid-Schiff and acid phosphatase positive), which were also heavily laden with iron. A minor degree of erythrophagocytosis was seen. On electron microscopy the histiocytes had the characteristic appearance of Gaucher cells. Leucocyte $\beta$ glucosidase activity at $0.54 \mathrm{nmol} / \mathrm{h}$ per $\mathrm{mg}$ protein (controls $13.9 \pm 4.7$ units, $n=16$ ) was reduced to $4 \%$ normal whereas activity in leucocytes from the daughter was partially reduced $(47 \%)$ consistent with heterozygosity, although normal (121\%) $\beta$-glucosidase activity was found in the son's leucocytes. Diagnosis was confirmed on cultured fibroblasts from the patient, which had $12.6 \mathrm{nmol} / \mathrm{h}$ per $\mathrm{mg}$ protein $\beta$ glucosidase activity, control value being $432 \pm 78$ units $(n=4)$.

After establishing the diagnosis the only therapy given was transfusional support. Because of his ischaemic heart disease he was initially considered to be unfit for splenectomy.

On a subsequent admission in November 1983 his full blood count showed a haemoglobin of $6.3 \mathrm{~g} / \mathrm{dl}$, white cell count $12.2 \times 10^{9} / 1,7 \%$ neutrophils, $17 \%$ lymphocytes, $37 \%$ monocytes, $1 \%$ eosinophils, $38 \%$ blast cells and platelets $25 \times 10^{\%} / 1$. A bone marrow aspirate was diagnostic of acute myeloid-monocytic leukaemia (napthyl acetate esterase positive). Serum lysozyme was elevated at $54.0 \mathrm{mg} / 1$ (normal range 3.49.2).

He died of bronchopneumonia before any antileukaemic therapy was initiated. At autopsy, bone marrow, spleen, liver and lymph nodes were infiltrated by both leukaemic and Gaucher cells. 


\section{Discussion}

An association between Gaucher disease and acute leukaemia was first suggested by Gelfand \& Gribroff, ${ }^{2}$ who reported the development of acute leukaemia in two patients with Gaucher disease. One, a 60 year old man, developed acute myeloid leukaemia and the other, a 55 year old man, progressed to acute lymphoblastic leukaemia. A further two patients with adult Gaucher disease developing acute myeloid leukaemia, have been reported ${ }^{3}$ both patients died during induction therapy. Rosner ${ }^{5}$ described a 6 year old child with acute lymphoblastic leukaemia, Gaucher cells in his marrow and a family history of Gaucher disease, although enzymatic diagnosis was not established. In 1985 , two cases of acute lymphoblastic leukaemia (ALL), one T-ALL and the other cALL, were described developing in children with Gaucher disease. ${ }^{4}$

The presence of Gaucher-like cells in the bone marrow has been well documented in patients with leukaemia, particularly chronic myeloid leukaemia. ${ }^{6,7}$ However, in these cases $\beta$-glucosidase activity has been normal or increased and the presence of these cells

\section{References}

1. Brady, R.O. \& Barranger, J.A. Glucosylceramide lipidosis: Gaucher's disease. In Stanbury, J.B., Wyngaarden, J.B., Fredrickson, D.S., Goldstein, J.L. \& Brown, M.S. (eds) Metabolic Basis of Inherited Disease, 5th ed. McGraw-Hill, New York, 1983, pp 842-856.

2. Gelfand, M.I. \& Gribroff, S.I. Gaucher's disease and acute leukaemia. J Mt Sinai Hosp N Y 1961, 28: 278282.

3. Krause, J.R., Bures, C. \& Lee, R.E. Acute leukaemia and Gaucher's disease. Scand J Haematol 1979, 23: 115-118.

4. Burstein, Y., Rechavie, G., Rausen, A.R. et al. Association of Gaucher's disease and lymphoid malignancy in 2 children. Scand J Haematol 1985, 35: 445-447.

5. Rosner, F., Dosik, H., Kaiser, S.S., Lee, S.L. \& Morrison, A.N. Gaucher cells in leukaemia. JAMA 1969, 209: 935-937.

6. Albrecht, M. 'Gaucher-Zellen' bei chronisch myeloischer Leukamie. Blut 1966, 13: 169-179. may reflect an excess of phagocytic activity secondary to increased white cell turnover. In our patient however, $\boldsymbol{\beta}$-glucosidase activity in both leucocytes and fibroblasts as well as spleen and brain, ${ }^{8}$ was reduced, consistent with the diagnosis of Gaucher disease. Heo also had one child, apparently heterozygous for thiso condition.

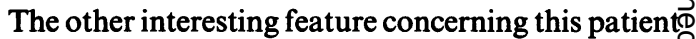
was his late age of presentation. A few older patients have been reported, ${ }^{9-11}$ but all these patients were ${ }^{\text {s }}$ Jewish and in some the diagnosis was incidental or $\vec{\circ}$ followed family studies. Our patient was Scottish presenting at 67 years of age and his development of acute myeloid/monocytic leukaemia again raises the question of an association between Type 1 Gaucher3. disease and malignancy. ${ }^{12}$

\section{Acknowledgement}

We should like to thank $\mathrm{Dr}$ Gaddie of Peel Hospitalo Galashiels for referring this patient.

7. Lee, R.E. \& Ellis, L.D. The storage cells of chrome myelogenous leukaemia. Lab Invest 1971, 24: 261-2 $\overline{4}$

8. Besley, G.T.N. \& Elleder, M. Enzyme activities antdo phospholipid storage patterns in brain and spleen samples from Neimann-Pick disease variants: a comparisono of neuropathic and non-neuropathic forms. $J$ Inheritedo Metab Dis 1986, 9: 59-71.

9. Brinn, L. \& Glaubman, S. Gaucher's disease without $\Rightarrow$ splenomegaly: oldest patient on record, with review. $N Y$ 의 State J Med 1962, 62: 2346-2354.

10. Chang-Lo, M., Yam, L.T. \& Rubenstone, A.I. Gau cher's disease: Review of the literature and report of twelve new cases. Am J Med Sci 1967, 254: 303-315.

11. Beutler, E. Gaucher's disease in an asymptomatic 72 year. old. JAMA 1977, 237: 2529.

12. Lee, R.E. The high incidence of malignant tumours in adults with Gaucher's disease. Lab Invest 1981, 44: 37A. 